\title{
IDENTIFIKASI GELOMBANG KELVIN DI LAPISAN TROPOPAUSE INDONESIA BAGIAN BARAT DENGAN MENGGUNAKAN DATA SOUNDING NOAA
}

\author{
Cornelius Antoni Nababan ${ }^{1}$
}

\begin{abstract}
Kelvin waves that previously observed in the lower stratosphere in the Indian and western Pacific region. Indonesia's position is between the two areas allowing the Kelvin wave in parts of Indonesia. However, the observed character is not necessarily the same. In JJAS period, the observed Kelvin waves have a period of 10-20 days meanwhile in DJFM period Kelvin waves detected on a period of 20 day. The Kelvin wave propagates eastward. The existence of a large convective activity in the territory of Indonesia is able to disrupt the Kelvin wave propagation. Convective clouds is shown by using the OLR data. In JJAS period, the strong disturbance in the earth's north while in the DJFM period in equator. The existence of such disorders can increase the wind easterlies thus increasing the amplitude of the wave in the northern parts of the earth on the JJAS and southern parts of the earth on DJFM. From the analysis of the 500-150 mb layer, visible presence of 20 days oscillations (JJAS) and 10-20 days (DJFM) with upward propagation. This condition indicates that the Kelvin wave observed at the tropopause layer raised from the bottom. Kelvin waves are observed close to the source generator.
\end{abstract}

\section{Intisari}

Gelombang Kelvin, Tropopause, Angin zonal. Gelombang Kelvin yang sebelumnya teramati pada lapisan stratosfer bawah berada di wilayah India dan Pasifik barat. Posisi Indonesia yang berada diantara dua wilayah tersebut memungkinkan terjadinya gelombang Kelvin di wilayah Indonesia. Namun, karakter yang teramati belum tentu sama. Pada bulan JJAS, gelombang Kelvin yang teramati memiliki periode 10-20 harian sedangkan pada bulan DJFM memiliki periode 20 harian. Gelombang Kelvin tersebut merambat ke timur. Adanya aktivitas konvektif yang besar di wilayah Indonesia mampu mengganggu perambatan gelombang Kelvin. Awanawan konvektif tersebut ditunjukkan dengan menggunakan data OLR. Pada periode JJAS, gangguan tersebut kuat pada bagian bumi utara sedangkan pada periode DJFM pada ekuator. Adanya gangguan tersebut dapat meningkatkan angin timuran sehingga meningkatkan amplitudo gelombang di bagian bumi utara pada JJAS dan bagian bumi selatan pada DJFM. Dari analisis pada lapisan 500-150 mb, terlihat adanya osilasi 20 harian (JJAS) dan 10-20 harian (DJFM) dengan perambatan ke atas. Kondisi ini menunjukkan bahwa gelombang Kelvin yang teramati pada lapisan tropopause dibangkitkan dari bawah. Gelombang Kelvin yang teramati dekat dengan sumber pembangkitnya.

Kata kunci : Gelombang Kelvin, Tropopause, Angin zonal.

\section{PENDAHULUAN}

Dinamika atmosfer pada lapisan stratosfer bawah (hingga tropopause) didominasi oleh Quasi-Biennial Oscilation (QBO). QBO dipercaya dibangkitkan dari hasil interaksi gelombang ekuatorial dengan aliran dasar. Perambatan secara vertikal ke atas dari gelombang berskala planeter tersebut mampu membangkitkan perubahan pada

\footnotetext{
Perekayasa UPT Hujan Buatan BPP Teknologi,

E-mail: cornelius.antoni@bppt.go.id
}

aliran-dasar di lapisan stratosfer-bawah zona ekuatorial melalui mekanisme interaksi gelombang dengan aliran-dasar. QBO mempunyai pengaruh terhadap sistem sirkulasi secara global yang berkaitan dengan berbagai masalah lingkungan.

Gelombang ekuatorial berskala planeter yang teramati di troposfer atas hingga stratosfer bawah adalah gelombang Kelvin dan Rossby-gravity. Gelombang Kelvin dengan periode 15-20 harian pertama kali ditemukan oleh Wallace dan Kousky pada tahun 1968 di pasifik barat (pada koordinat $9^{\circ}$ 
LU dan $80^{\circ} \mathrm{BT}, 11^{\circ} \mathrm{LU}$ dan $61^{\circ} \mathrm{BT}$, dan $9^{\circ} \mathrm{LU}$ dan $168^{\circ} \mathrm{BT}$ ) dan Dhaka et al. (1995) juga menemukan gelombang Kelvin dengan periode 7-16 harian di wilayah India (pada koordinat $8.5^{\circ} \mathrm{LU}$ dan $77^{\circ} \mathrm{BT}$, 8. $3^{\circ} \mathrm{LU}$ dan $73^{\circ} \mathrm{BT}, 11.7^{\circ} \mathrm{LU}$ dan $92.7^{\circ} \mathrm{BT}$ ) pada ketinggian $12-16 \mathrm{~km}$ (troposfer atas). Gelombang Rossby-gravity dengan perode 4-5 harian pertama kali ditemukan oleh Yanai dan Maruyama pada tahun 1966 juga di wilayah pasifik barat ( $3^{\circ}$ LS dan $\left.172^{\circ} \mathrm{BB}\right)$.

Gelombang Kelvin berbentuk simetris dengan puncak berada di ekuator dan meluruh jika menjauhi ekuator. Gelombang Kelvin yang pertama kali ditemukan memiliki panjang gelombang 20.000 $\mathrm{km}$ dan panjang gelombang vertikalnya $6-10 \mathrm{~km}$. Gelombang Kelvin berpropagasi ke timur (secara zonal) dan ke bawah (secara vertikal).

Penelitian inimengkajigelombang Kelvinyang berada di tropopause ekuatorial Indonesia dengan menggunakan data sounding NOAA dengan objek kajian Indonesia bagian barat yaitu pada batasan wilayah $95^{\circ} \mathrm{BT}-110^{\circ} \mathrm{BT}$ dan $10^{\circ} \mathrm{LU}-10^{\circ} \mathrm{LS}$ dengan pembagian grid pada jarak $5^{\circ}$. Adapun pemilihan lapisan tropopause adalah karena lapisan tersebut merupakan lapisan yang stabil sehingga memungkinkan terjadinya perambatan gelombanggelombang atmosfer baik berskala besar maupun berskala kecil. Objek studi ini melibatkan unsur medan angin mencakup komponen zonal dan meridional sebagai objek utama yang akan dikaji, serta suhu udara, kelembaban dan ketinggian geopotensial sebagai objek penunjang. Tulisan ini bertujuan untuk mengidentifikasi gelombang Kelvin yang teramati di lapisan tropopause Indonesia bagian Barat dan mempelajari karakternya.

\subsection{Teori Gelombang Kelvin}

Gelombang kelvin pertama kali ditemukan oleh Wallace dan Kousky (1968) di stratosfer bawah ekuatorial. Gelombang Kelvin muncul ketika aliran dasar timuran dimana gelombang ini merambat ke timur dengan kecepatan $+25 \mathrm{~m} / \mathrm{s}$ relatif terhadap permukaan bumi. Gelombang Kelvin memiliki periode 10-20 hari. Namun ada juga yang periodenya 7-10 hari (pada stratosfer atas) yang dikenal dengan Fast Kelvin (FK) dan juga periodenya 3-4 hari (pada lapisan mesosfer dan thermosfer bawah) yang dikenal dengan Ultra Fast Kelvin (UFK) (Lima et al., 2008). Gelombang Kelvin memiliki panjang gelombang vertikal sekitar 6-10 km dan memiliki 1-2 bilangan gelombang zonal. Skala meridional gelombang Kelvin berkisar 1300-1700 km (Holton, 2004). Gelombang Kelvin muncul pada ketinggian 16-60 km dengan periode dan panjang gelombang dalam arah vertikal yang berbeda-beda (Dhaka et al., 1995).

Dari persamaan pertubasi linier pada perairan dangkal (Holton 2004):

$\partial u^{\prime} / \partial t-b y u^{\prime}=-\partial \Phi^{\prime} / \partial x$

$\partial \mathrm{u}^{\prime} / \partial t+\mathrm{b} y u^{\prime}=-\partial \Phi^{\prime} / \partial y$

$\partial \Phi^{\prime} / \partial t+g h_{e}\left(\partial u^{\prime} / \partial x+\partial u^{\prime} / \partial y\right)=0$

dimana: $\Phi^{\prime}$ = gh' merupakan pertubasi geopotensial dan diasumsikan bahwa solusi persamaan gelombang mempunyai bentuk:

$\left(\begin{array}{l}u^{\prime} \\ u^{\prime} \\ \Phi^{\prime}\end{array}\right)=\left[\begin{array}{c}\hat{u} \\ \hat{u} \\ \hat{\Phi}\end{array}\right] \exp [i(k x-v)]$

Substitusikan persamaan (4) ke dalam persamaan (1)-(3) maka akan dihasilkan

$$
\begin{aligned}
& -v u-\mathrm{byu}=-i k \Phi \\
& -i v \mathrm{u}+\mathrm{b} y u=-\partial \Phi / \partial y \ldots \ldots \ldots . . . . . . . . . . \\
& -i v \Phi+g h_{e}(i k u+\partial \mathrm{u} / \partial y)=0
\end{aligned}
$$

Ciri khas dari gelombang Kelvin adalah tidak adanya pertubasi kecepatan dalam arah meridional sehingga komponen meridional pada persamaan (5)-(7) dapat dihilangkan.

$$
\begin{aligned}
& -i v \hat{\wedge}=-i k \hat{\wedge} \\
& \text { by } u=-\partial \hat{\Phi} / \partial y \\
& -i v \hat{\Phi}+g h_{e}(i k \hat{u})=0
\end{aligned}
$$

Kombinasi persamaan (8) dengan (10) akan menghasilkan persamaan dispersi gelombang Kelvin yang identik dengan gelombang gravityperairan dangkal dimana: Kombinasi persamaan (8) dengan (10) akan menghasilkan persamaan dispersi gelombang Kelvin yang identik dengan gelombang gravity-perairan dangkal dimana:

$$
c \equiv(v / k)=g h_{e}
$$

Sedangkan hasil kombinasi persamaan (8) dengan (9) diperoleh persamaan differensial orde satu yang menyatakan kebergantungan $u$ dalam arah meridional:

by $u=-c \partial u / \partial y$

Solusi persamaan (12) menghasilkan:

$u_{0} \exp \left(\mathrm{by}^{2} / 2 \mathrm{c}\right)$

Dengan $\hat{u}_{0}$ merupakan amplitudo dari pertubasi angin zonal di ekuator. Pertubasi ketinggian geopotensial gelombang Kelvin bervariasi terhadap lintang dimana mengikuti fungsi Gaussian yang berpusat di ekuator.

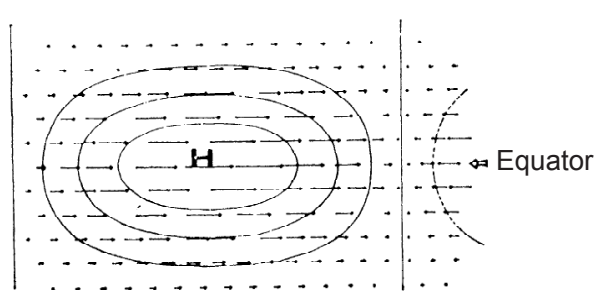

Gambar 1. Profil horizontal Gelombang Kelvin (Matsuno, 1966).catchment area Situ Gintung 


\section{DATA DAN PENGOLAHAN}

Data yang akan digunakan dalam penelitian ini adalah data sounding harian level $100 \mathrm{mb}$ yang merupakan data estimasi dari Satelite NOAA pada bulan Juni, Juli, Agustus, September, Desember 2007 dan Januari, Februari, Maret 2008 (untuk seterusnya disebut JJAS dan DJFM). Pemilihan periode tersebut karena pada periode JJAS dan DJFM merupakan kondisi ekstrim kering dan basah. Data didapat dari NOAA (2008).

Analisis yang digunakan untuk mengestimasi fungsi densitas spektrum dari sebuah deret waktu adalah analisis spektral. Analisis spektral merupakan modifikasi dari analisis Fourier sehingga analisis ini sesuai untuk deret waktu yang stokastik (Chatfield,1989). Secara definisi, jika Xt adalah proses stokastik dengan fungsi autokovarian $\mathrm{\gamma}(\mathrm{k})$ dengan $\mathrm{k}=\ldots,-2,-1,0,1,2, \ldots$, maka spektrum $f(\omega)$ adalah transformasi Fourier dari fungsi autokovariansi, yang dalam ekspresi matematisnva adalah sebagai berikut:

$$
f(\mathrm{w})=\frac{1}{\mathrm{p}} \sum_{k=-\infty}^{\infty} \mathrm{g}(k) \exp (-i \mathrm{w} k)
$$

Sedangkan untuk melihat propagasi dari gelombang Kelvin tersebut digunakan analisis spektral silang. Analisis spektral silang merupakan metode yang alami digunakan untuk melihat hubungan antara dua deret waktu dalam selang waktu yang sama (Chatfield,1989). Dengan menggunakan analogi pada persamaan (14) dimana $\mathrm{g}_{x y}(k)$ merupakan fungsi cross-kovarian antar dua proses bivariat $\mathrm{Xt}$ dan $\mathrm{Yt}$ dengan $\mathrm{k}=$ $\ldots,-2,-1,0,1,2, \ldots$, maka fungsi spektral silang dapat didefinisikan dengan:

$f_{x y}(\mathrm{w})=\frac{1}{\mathrm{p}} \sum_{k=-\infty}^{\infty} \mathrm{g}_{y y}(k) \exp (-i \mathrm{w} k)$

Dengan menggunakan formula Euler, maka diperoleh beberapa persamaan untuk menginterpretasikan spktrum silang:

$$
\begin{aligned}
& \text { a) co-spektrum, dengan persamaan } \\
& \text { matematis: }
\end{aligned}
$$$$
c(\mathrm{w})=\frac{1}{\mathrm{p}} \sum_{k=-\infty}^{\infty} \mathrm{g}_{y}(k) \cos (\mathrm{w} k)
$$

b) quadrature spektrum, dengan persamaan matematis:

$q(\mathrm{w})$

$$
=\frac{1}{\mathrm{p}} \sum_{k=1}^{\infty}\left(\mathrm{g}_{y y}(k)-\mathrm{g}_{y}(k)\right) \sin (\mathrm{w} k)
$$

c) cross-amplitudo spektrum, dengan persamaan matematis:

$\sqrt{a_{x y}(w)=\left[c^{2}(w)+q^{2}(w)\right]}$

d) phase spectrum, dengan persamaan matematis:

$\left.\varnothing_{x y}(\mathrm{w})=\operatorname{Tan}^{-1}[-q \mathrm{w}) / c(\mathrm{w})\right]$

e) coherency, dengan persamaan matematis:

$\left.c(\mathrm{w})=a_{x y}^{2}(\mathrm{w}) / f_{x}(\mathrm{w}) f_{y}(\mathrm{w})\right]$

f) gain spektrum, dengan persamaan matematis:

$G_{x y}(\mathrm{~W})=a_{x y}(\mathrm{~W}) / f_{x}(\mathrm{~W})$

Dalam penelitian ini, fungsi spektral silang yang akan digunakan adalah amplitudo, koherensi dan fasa.

\section{HASIL DAN PEMBAHASAN}

\subsection{Periode JJAS (Juni-Juli-Agustus- September)}

\subsubsection{Analisis spektral}

Hasil analisis spektral angin zonal di lapisan tropopause pada periode JJAS menunjukkan adanya osilasi dengan periode dalam selang 10-20 harian. Osilasi tersebut memiliki periode yang berbeda-beda pada setiap lintang. Osilasi tersebut muncul pada bujur $100^{\circ}$ dan $105^{\circ} \mathrm{BT}$ dan nilai kerapatan spektral pada $105^{\circ} \mathrm{BT}$ lebih besar daripada $100^{\circ} \mathrm{BT}$.

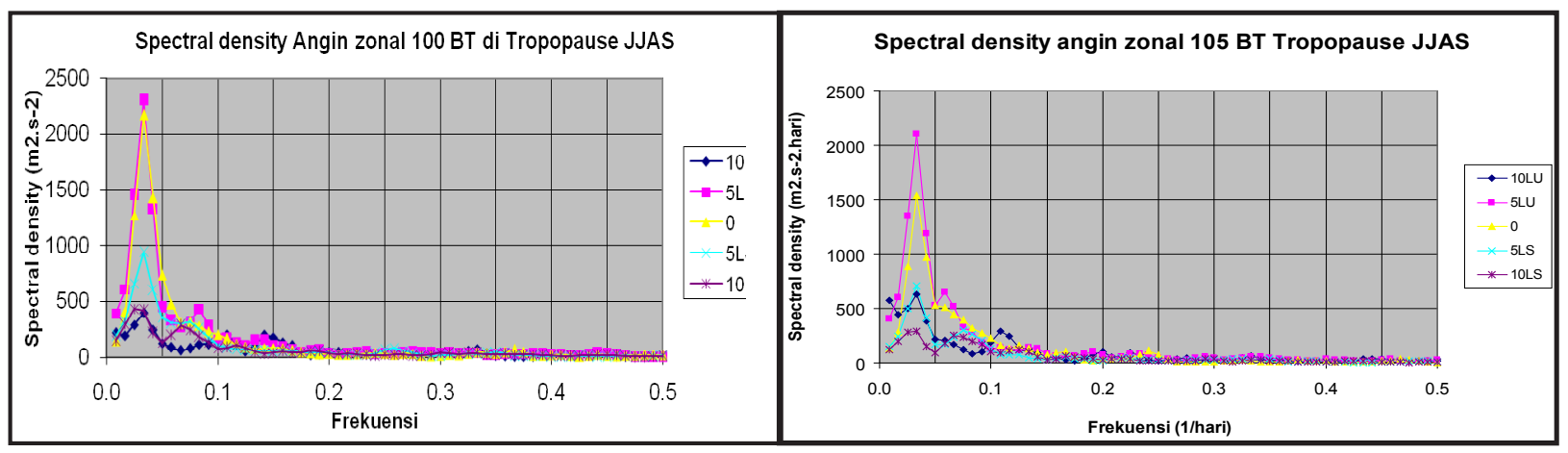




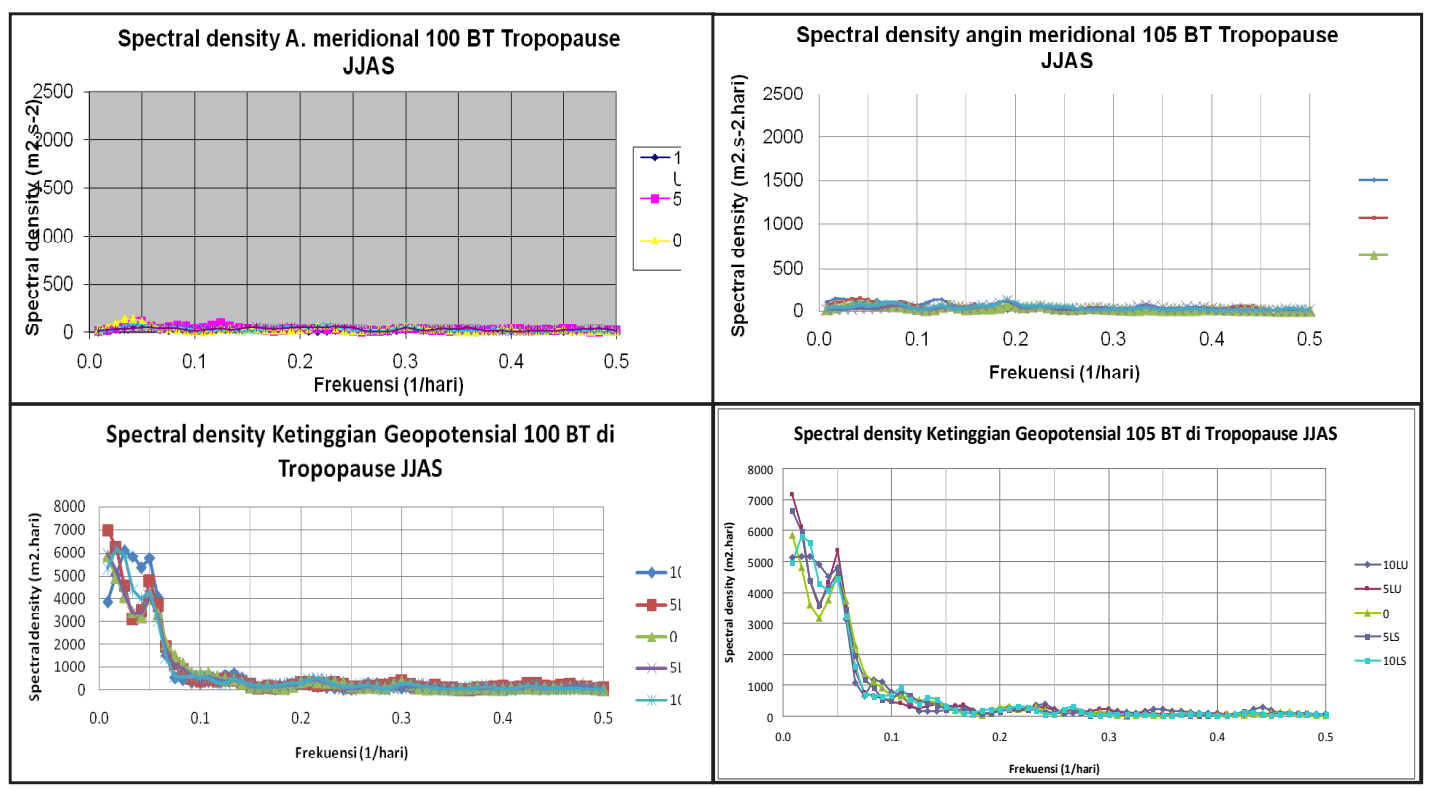

Gambar 2. Kerapatan spektral: a) angin zonal, b) angin meridional c) ketinggian geopotensial pada 100 BT (kiri) dan 105 BT (kanan) level tropopause JJAS.

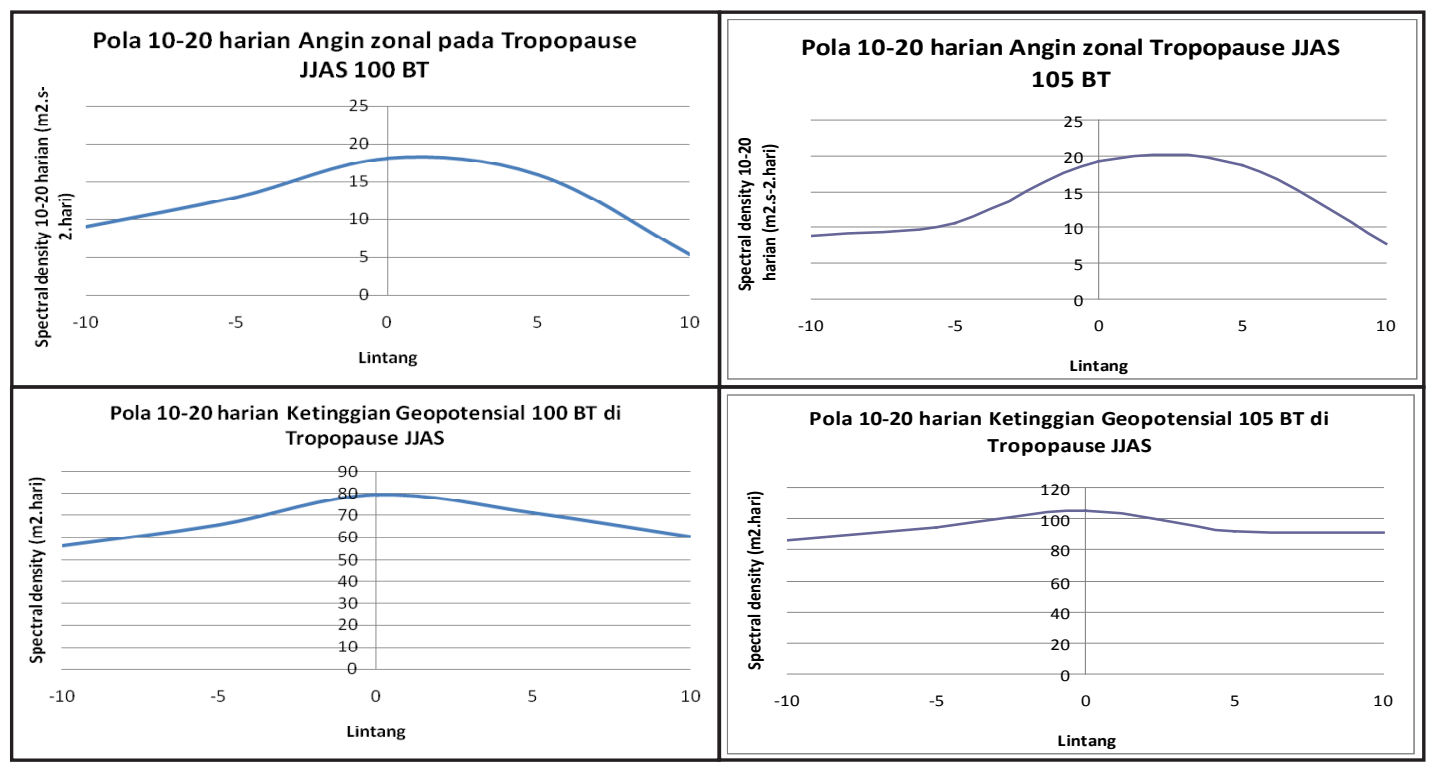

Gambar 3. Sebaran osilasi 10-20 harian terhadap lintang pada: a) angin zonal dan b) ketinggian geopotensial pada 100 BT (kiri) dan 105 BT (kanan) JJAS.

Pada hasil analisis spektral pada ketinggian geopotensial juga menunjukkan adanya osilasi 20 harian yang muncul secara seragam pada setiap lintang pada bujur $100^{\circ}$ dan $105^{\circ} \mathrm{BT}$. Pada ketinggian geopotensial kerapatan spektral lebih kecil pada bujur $105^{\circ} \mathrm{BT}$. Sedangkan hasil analisis spektral pada angin meridional tidak menunjukkan adanya periode yang seragam pada 20 harian atau 10-20 harian. Sehingga dapat diduga bahwa osilasi ini merupakan gelombang Kelvin dimana pada gelombang Kelvin tidak ada osilasi komponen angin meridional.

Mengacu pada persamaan 13, maka secara teoritik angin zonal pada gelombang Kelvin akan memiliki sebaran Gaussian dengan nilai puncak berada tepat pada ekuator. Dengan melihat sebaran spektral angin zonal dan ketinggian geopotensial (Gambar 3), hasil ini mirip dengan bentuk sebaran gelombang Kelvin. Nilai spektrum angin zonal dan ketinggian geopotensial lebih tinggi pada 105 BT daripada $100 \mathrm{BT}$. Hal tersebut menunjukkan energi yang lebih besar pada 105 BT. Sebaran pada angin zonal spektral dan ketinggian geopotensial terdapat peningkatan amplitudo pada lintang utara $\left(5^{\circ} \mathrm{LU}\right.$ dan $10^{\circ} \mathrm{LU}$ ). Kondisi ini disebabkan karena aktivitas konvektif lebih intensif terjadi di lintang utara. Hal ini juga ditandai adanya peningkatan angin timuran pada lintang utara yang mengakibatkan meningkatnya amplitudo gelombang Kelvin pada lintang utara. Perlu studi lebih lanjut untuk menjelaskan penyebab peningkatan angin timuran tersebut. 


\subsubsection{Analisis spektral silang}

Hasil analisis spektral menunjukkan hadirnya gelombang Kelvin dengan periode 10-20 harian pada bujur $100^{\circ}$ dan $105^{\circ} \mathrm{BT}$. Dari hasil analisis spektral silang angin zonal antara bujur $100^{\circ}$ BT dengan $105^{\circ} \mathrm{BT}$, osilasi angin zonal dengan periode 20 harian yang ada pada $100^{\circ} \mathrm{BT}$ memiliki koherensi yang tinggi dengan pada $105^{\circ} \mathrm{BT}$ (Tabel 1).

Wallace dan Kousky (1968) mengidentifikasi gelombang Kelvin di stratosfer-bawah pasifik-barat dengan periode lebih dari 10 hari. Holton (2004) menegaskan bahwa gelombang Kelvin yang diamati Wallace dan Kousky memiliki periode 10-20 harian. Sedangkan Dhaka (1995) mengidentifikasi gelombang Kelvin dengan periode 12-16 pada level 16-24 km di wilayah India.

Pada bulan JJAS, terdapat variasi jeda waktu perambatan angin zonal antara $100^{\circ} \mathrm{BT}$ dengan $105^{\circ}$ BT pada berbagai lintang. Jeda waktu yang terbesar berkisar 3,6 hari dimana jeda waktunya akan semakin kecil jika semakin ke utara. Jeda waktu yang sangat kecil pada $10^{\circ} \mathrm{LU}$ menunjukkan bahwa sumber energipembangkitgelombang Kelvin berada di utara. Jika semakin jauh dari sumber pembangkitnya jeda waktu gelombang Kelvin akan semakin besar. Pada $10^{\circ} \mathrm{LU}$, gelombang Kelvin dapat dikatakan dalam kondisi stationary (nilai beda fasanya kecil). Besarnya konvektif di tropis dapat mengganggu perambatan dari gelombang Kelvin. Pada bulan JJAS, matahari berada di utara yang mengakibatkan konvektif terbesar terjadi di utara. Kondisi ini yang mengubah perambatan horizontal gelombang Kelvin pada bagian bumi utara.

Spektrum suhu pada $100^{\circ}$ BT memiliki koherensi yang tinggi dengan $105^{\circ}$ BT. Hasil spektral silang suhu antara $100^{\circ} \mathrm{BT}$ dengan $105^{\circ}$ BT menunjukkan beda fasa yang negatif. Hal ini menunjukkan bahwa perambatan suhu dari timur menuju barat. Sedangkan pada ketinggian geopotensial beda fasa antara $100^{\circ}$ BT dan $105^{\circ}$ BT bernilai positif dengan nilai koherensi yang tinggi. Perambatan ketinggian geopotensial sama dengan angin zonal, ke arah timur. Secara teoritik angin zonal sefasa dengan ketinggian geopotensial. Dengan kata lain kenaikan angin zonal akan diikuti dengan kenaikan ketinggian geopotensial pada dua data time series (memiliki pola yang sama).

Peningkatan suhu tidak langsung diikuti oleh peningkatan angin zonal. Ada jeda waktu yang memisahkan angin zonal dengan suhu. Secara teoritik, Holton (2004) menjelaskan bahwa pada gelombang Kelvin suhu akan mendahului angin zonal sebesar $1 / 4$ fasa. Suhu dengan angin zonal memiliki koherensi yang tinggi.

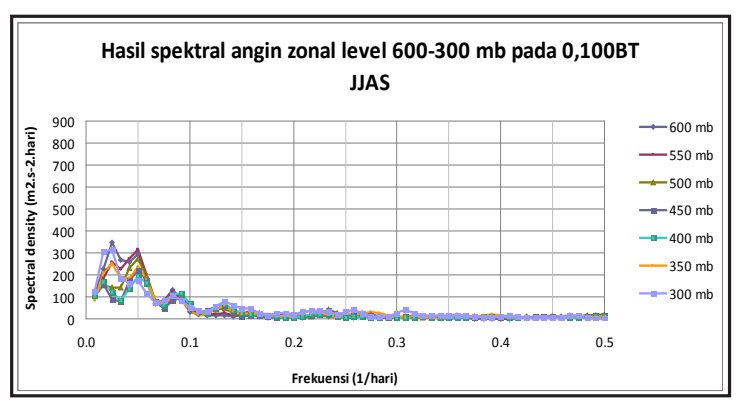

Gambar 4. Kerapatan spektral angin zonal antara level $600 \mathrm{mb}$ - $300 \mathrm{mb}$ pada $0^{\circ}$ dan $100^{\circ} \mathrm{BT}$ pada bulan JJAS.

Pada level $600 \mathrm{mb}$ hingga $300 \mathrm{mb}$ pada koordinat $0^{\circ}, 100^{\circ} \mathrm{BT}$ terdapat osilasi dengan periode 20 harian. Namun, pada level $250-150$ periode osilasi tersebut berada dalam selang 1020 harian Gelombang Kelvin yang terdapat pada level tropopause diduga merupakan gelombang yang dekat dengan pembangkitnya (forced wave). Koherensi antar lapisan pada level 600 - 300 mb tinggi pada osilasi 20 harian sedangkan pada lapisan 250 - 150 mb koherensi antar lapisan kecil. Selain itu, beda fasa antar lapisan pada level 600-400 mb bernilai positif. Hal ini menunjukkan bahwa gangguan angin zonal dengan periode 20 harian tersebut dibangkitkan dari bawah. Namun pada level 400-300 mb dan 200-150 mb beda fasa bernilai negatif. Kondisi ini menunjukkan adanya gangguan pada level tersebut.

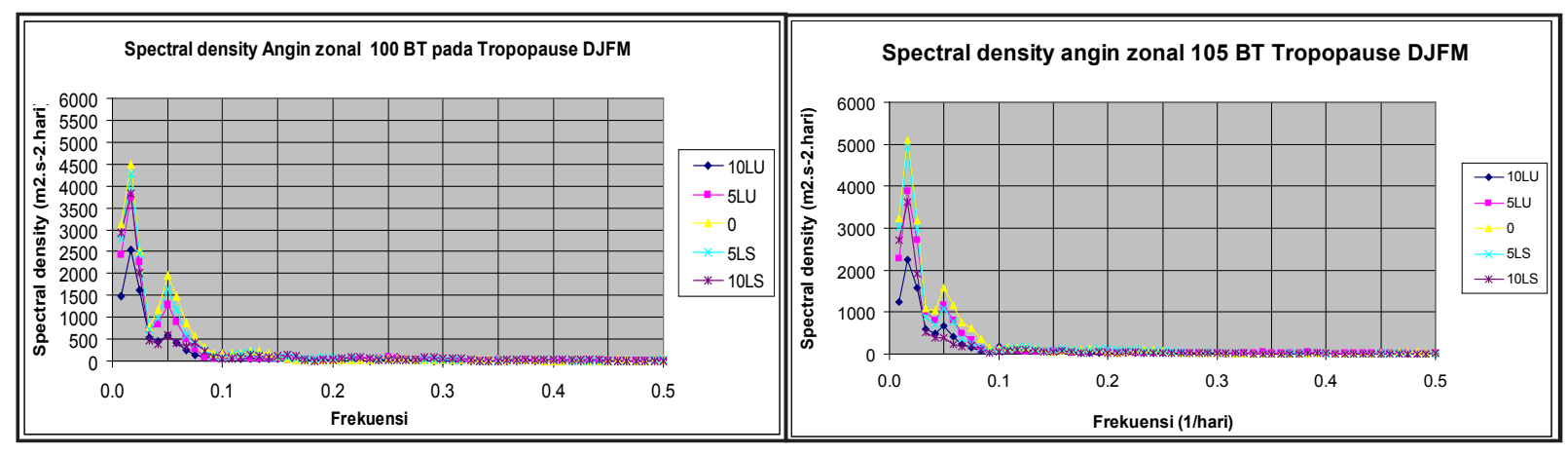




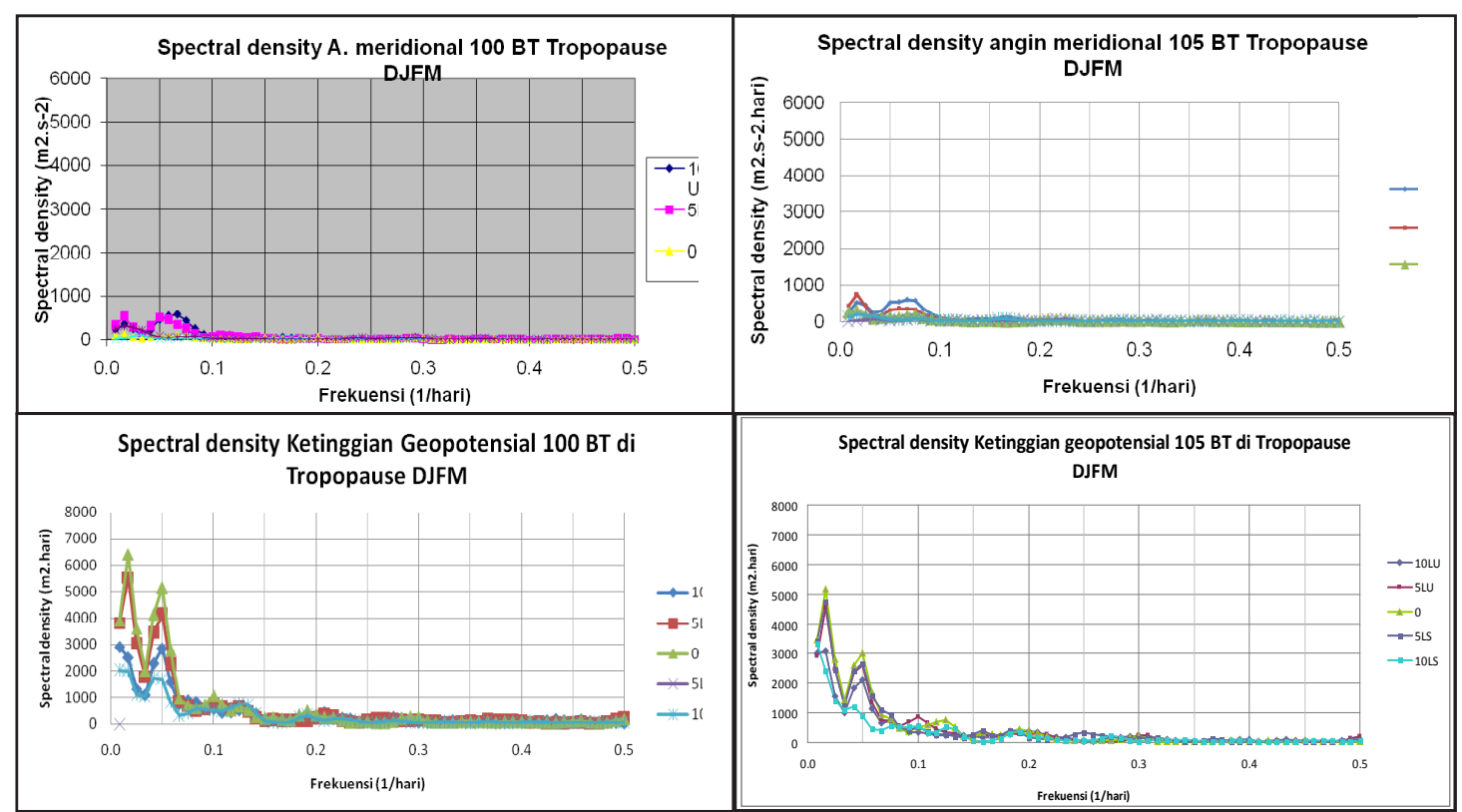

Gambar 5. Kerapatan spektral:a) angin zonal, b) angin meridional, c) Ketinggian geopotensial pada 100 BT (kiri) dan 105 BT (kanan) level tropopause DJFM.

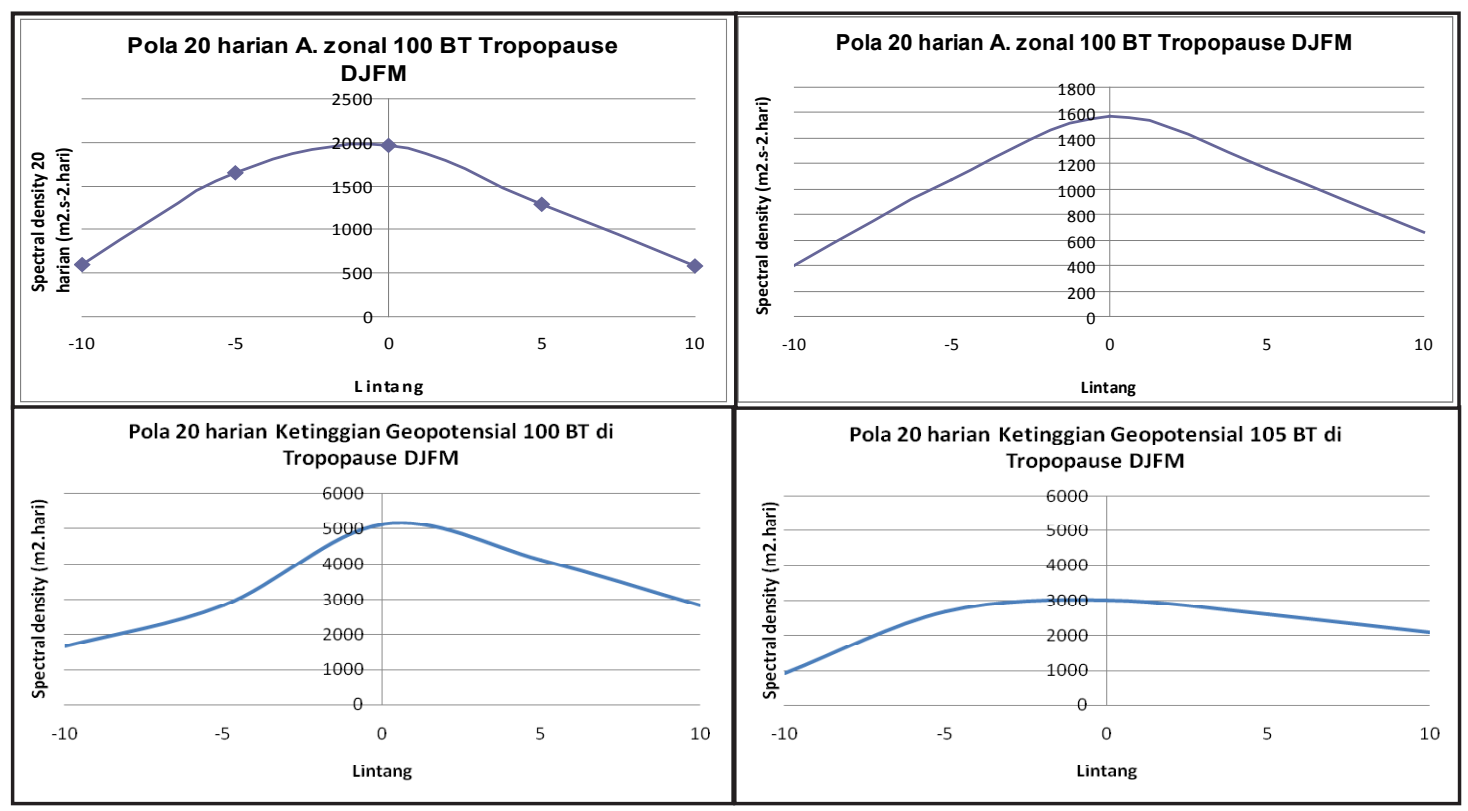

Gambar 6. Sebaran osilasi 20 harian terhadap lintang pada: a) angin zonal, dan b) ketinggian geopotensial pada 100 BT(kiri) dan 105 BT (kanan) DJFM.

\subsection{Periode DJFM}

\subsubsection{Analisis spektral}

Hasil analisis spektral angin zonal bulan DJFM juga menunjukkan adanya osilasi dengan periode 20 harian pada lapisan tropopause (100 $\mathrm{mb}) 100^{\circ} \mathrm{BT}$. Osilasi 20 harian juga muncul pada $105^{\circ}$ BT namun dengan nilai spektral density yang lebih rendah. Demikian juga pada suhu, juga menunjukkan hasil yang sama dengan pada angin zonal. Pada variable suhu, osilasi pada level tropopause di koordinat $10^{\circ} \mathrm{LU}, 100^{\circ} \mathrm{BT}$ dan di $10^{\circ}$ $\mathrm{LU}, 105^{\circ} \mathrm{BT}$ mempunyai puncak yang tegas pada periode 20 harian. Osilasi 20 harian juga muncul pada spektrum ketinggian geopotensial. Sebaran spektrum 20 harian angin zonal, suhu dan ketinggian geopotensial pada level tropopause menunjukkan bahwa densitas spektral memiliki puncak tertinggi di ekuator dan meluruh bila menjauhi ekuator. Pola seperti ini juga terlihat pada titik $105^{\circ}$ BT. Hasil ini menguatkan dugaan bahwa osilasi yang terjadi pada bulan DJFM juga merupakan gelombang Kelvin dengan periode 20 harian. 
Matsuno (1966) menjelaskan bahwa gelombang Kelvin memiliki puncak tepat berada di ekuator dan akan meluruh bila semakin menjauhi ekuator (sebaran Gaussian). Dari hasil analisis spektral, osilasi dengan periode 20 harian tersebut mirip dengan gelombang Kelvin. Namun belum dapat dipastikan bahwa osilasi tersebut merupakan gelombang Kelvin.

Nilai spektrum pada bulan DJFM jauh lebih besar daripada bulan JJAS terutama pada variabel angin zonal dan ketinggian geopotensial. Kondisi ini menunjukkan bahwa intensitas gelombang Kelvin lebih besar pada bulan DJFM. Selain itu, energi pembangkit gelombang Kelvin pada bulan DJFM lebih besar daripada JJAS. Hal ini dapat terjadi karena awan-awan konvektif lebih banyak pada bulan DJFM.

\subsubsection{Analisis spektral silang}

Dari hasil analisis spektral silang pada bulan DJFM terlihat konsisten kehadiran gelombang Kelvin dengan periode 20 harian. Pada bulan DJFM, hubungan antara angin zonal, suhu antara $100^{\circ}-105^{\circ} \mathrm{BT}$ juga memiliki koherensi yang tinggi. Dari hasil analisis spektral silang terlihat keherensi antara $100^{\circ}$ BT dengan $105^{\circ}$ BT diatas 0.7 . Sedangkan perambatan gelombang Kelvin pada bulan DJFM juga ke arah timur (beda fasa positif).

Hal yang menarik adalah pada ekuator beda fasa angin zonal antara $100^{\circ}$ BT dengan $105^{\circ}$ BT bernilai negatif (sangat kecil). Kondisi ini menunjukkan pada terjadi peredaman perambatan gelombang Kelvin pada ekuator. Peredaman ini disebabkan kuatnya konvektif yang terjadi pada lapisan troposfer.

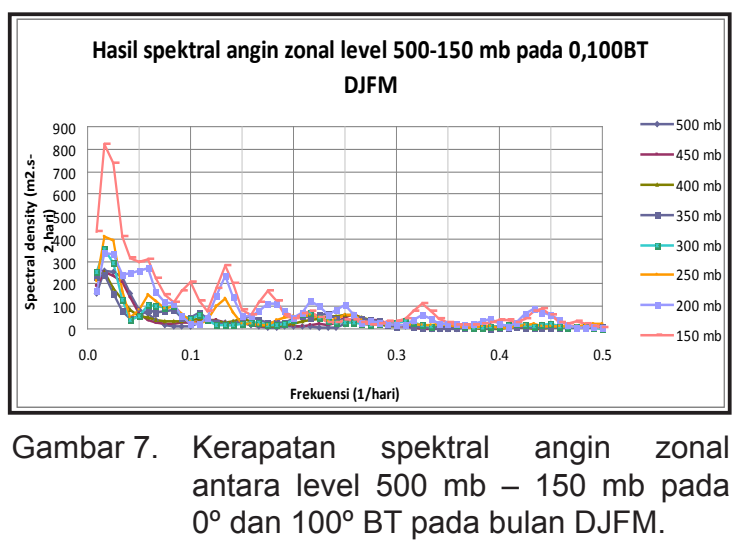

Hasil analisis spektral pada lapisan $500 \mathrm{mb}$ - 150 mb menujukkan adanya osilasi 10-20 harian. Koherensi antar level pada lapisan tersebut tinggi (> $0.5)$, namun koherensi antara level $105 \mathrm{mb}$ dengan $100 \mathrm{mb}$ (tropopause) sangat kecil (mendekati 0) dan beda fasa yang cukup besar. Dari kondisi tersebut dapat diduga bahwa osilasi 20 harian pada lapisan tropopause merupakan kondisi yang terpisah dari lapisan dibawahnya.

Kondisi tersebut tidak memberikan informasi bahwa osilasi 10-20 harian pada lapisan bawah merupakan bagian dari gelombang Kelvin pada lapisan tropopause. Namun dengan adanya ini kita mendapat informasi bahwa adanya energi yang besar di bawah gelombang Kelvin yang teramati di lapisan tropopause. Gelombang Kelvin yang terjadi merupakan gelombang yang dekat dengan sumbernya. Hal ini yang membedakan gelombang Kelvin yang terjadi di Indonesia bagian barat ini dengan gelombang Kelvin yang teramati di wilayah India (Dhaka, 1995) dan yang di wilayah Pasifik barat (Wallace dan Kousky, 1968).

\section{KESIMPULAN}

Padalapisantropopausejelasterlihathadirnya gelombang Kelvin dengan periode 10-20 harian pada JJAS dan 20 harian pada DJFM. Gelombang tersebut berpropagasi ke timur. Gelombang Kelvin yang teramati merupakan gelombang yang dekat dengan sumber pembangkitnya. Perbedaan gelombang Kelvin yang teramati di Indonesia dengan yang di India dan pasifik barat adalah adanya energi yang menghambat perambatan gelombang Kelvin di Indonesia. Pada bulan JJAS gangguan tersebut kuat pada $10 \mathrm{LU}$ sedangkan pada bulan DJFM pada ekuator.

\section{DAFTAR PUSTAKA}

Chatfield C. 1989. The Analysis of Time Series An Introduction. Chapman and Hall 2-6. boundary Row. London.

Dhaka, et al. 1995. A Study of Equatorial Waves in The Indian Zone. J. Atmos. and Terres. Phy. 57: 1189-1202. Elsevier Science Ltd: Great Britain.

Holton, J.R. 2004. An Introduction to Dynamic Meteorology. Fourth Edition. Elsevier Inc. USA.

Lima, L. et al. 2008. 3-4 day Kelvin wave observed in the MLT region at $7.4^{\circ} \mathrm{S}$, Brazil. Geofisica Internacional 47: 153-160.

Maruyama, T. 1967. Large-Scale Disturbances in the Equatorial Lower Stratosphere. J. Meteor. Soc. Jap. 45: 391-408.

Matsuno, T. 1966. Quasi-Geostropic Motions in the Equatorial Area. J. Meteor. Soc. Jap.44: 25-42.

Satriyani. 2007. Studi Identifikasi Pola Utama Data Radiosonde Melalui Analisis Komponen Utama dan Analisis Spektum (Studi Kasus Bandung). Skripsi. Fakultas Matematika dan IImu Pengetahuan Alam, Institut Pertanian Bogor. Bogor. (Tidak dipublikasikan) 

Wallace, J.M. dan Kousky, V.E. 1968.
Observational Evidence of Kelvin Waves in the Tropical Troposphere. J. Atmos. Sci. 25: 900-907.
Wei, W. W. S. 1994. Time Series Analysis: Univariate and Multivariate Methods. Addison-Wesley Publishing Company Inc. USA

www.arl.noaa.gov/ready/amet? 


\begin{tabular}{|c|c|c|c|c|c|c|}
\hline \multicolumn{2}{|c|}{ 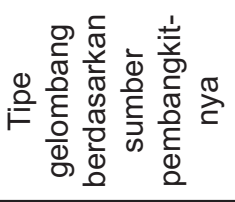 } & \multirow{2}{*}{ 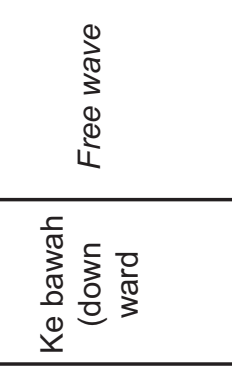 } & \multicolumn{2}{|r|}{ 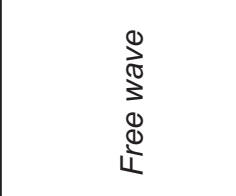 } & \multirow{2}{*}{\multicolumn{2}{|c|}{ 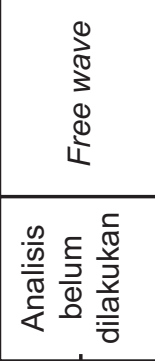 }} \\
\hline \multirow{2}{*}{ 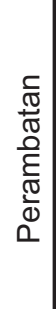 } & 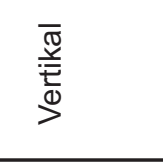 & & 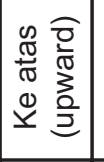 & 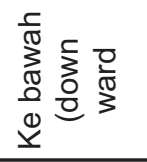 & & \\
\hline & 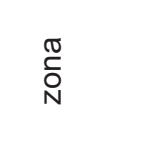 & 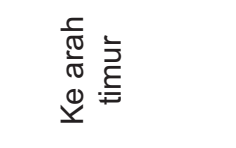 & 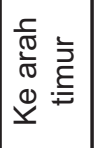 & 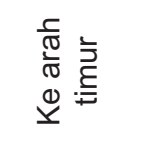 & 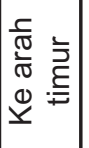 & 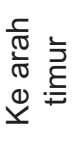 \\
\hline & 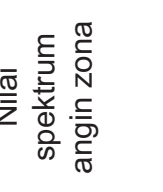 & $\stackrel{R}{+1}$ & \multicolumn{2}{|c|}{ 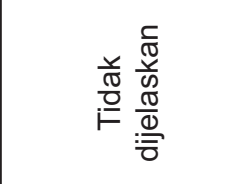 } & $\stackrel{\text { \& }}{\stackrel{\sim}{+}}$ & ষ্ণ \\
\hline & 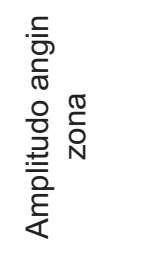 & $\begin{array}{l}\stackrel{\infty}{\varepsilon} \\
\stackrel{N}{N} \\
\stackrel{\infty}{0}\end{array}$ & 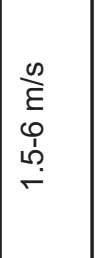 & $\begin{array}{l}\stackrel{\infty}{\xi} \\
\stackrel{p}{\sim} \\
\sim\end{array}$ & \multicolumn{2}{|c|}{ 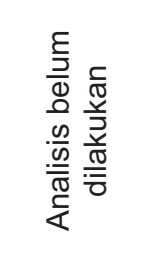 } \\
\hline & $\begin{array}{l}\text { O) } \\
\frac{\pi}{\pi} \\
\frac{0}{E} \\
\frac{0}{0} \\
0 \\
0 \\
0 \\
\frac{0}{0} \\
. \frac{0}{0} \\
0\end{array}$ & 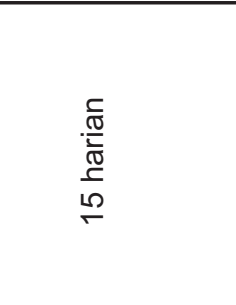 & 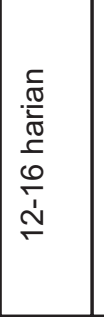 & $\begin{array}{l}\frac{c}{\sigma 0} \\
\frac{\pi}{\pi} \\
\frac{\pi}{0} \\
0 \\
0 \\
0 \\
0\end{array}$ & 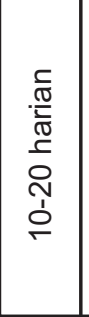 & 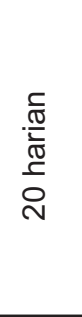 \\
\hline & 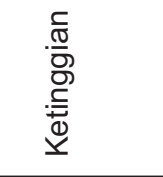 & $\begin{array}{l}\stackrel{0}{\varepsilon} \\
\frac{\rho}{1} \\
\stackrel{0}{\infty}\end{array}$ & 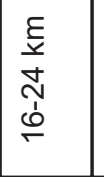 & $\begin{array}{l}\varepsilon \\
\frac{\varepsilon}{o} \\
⿱ 亠 \\
\infty \\
\infty \\
\infty\end{array}$ & \multicolumn{2}{|c|}{$\begin{array}{l}\text { 오 } \\
\text { ᄋ̊ }\end{array}$} \\
\hline & 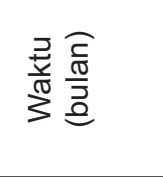 & 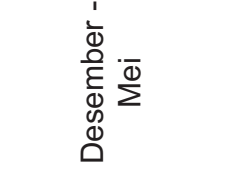 & \multicolumn{2}{|r|}{$\begin{array}{l}\overline{\overline{3}} \\
\cdot \overline{1} \\
\overline{0} \\
\sum\end{array}$} & 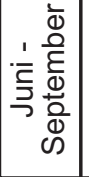 & 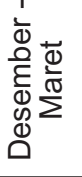 \\
\hline & 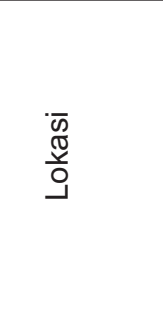 & 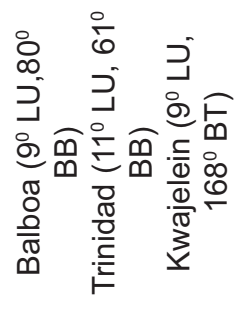 & 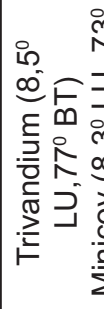 & 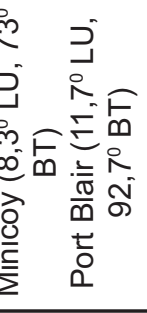 & 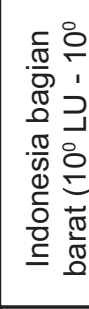 & 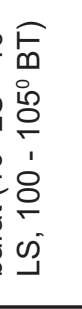 \\
\hline & 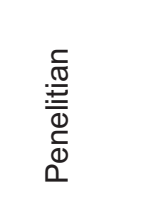 & 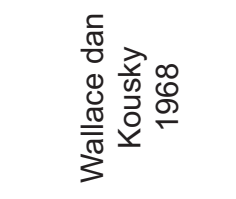 & & 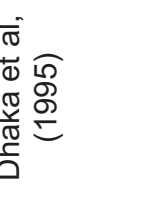 & 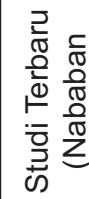 & \\
\hline
\end{tabular}


